\title{
TRES HÉROES DEL MUNDO MÍTICO KAWÉSQAR ${ }^{1}$
}

EUGENIA BRITO A."

\section{RESUMEN}

En el siguiente artículo, me propongo indagar la especificidad del lugar del héroe en dos cuentos kawésqar: el cuento de Annápas y el del ratón. A partir de la lectura y análisis de los textos orales de este grupo étnico del extremo sur de Chile, sostengo que la heroicidad, ligada siempre al carácter masculino, tiene una existencia única y diferenciada, que se manifiesta, en el primer caso, a través de una retórica de acciones ligadas a la confrontación y al poder y, en el segundo ejemplo, a la superación del abandono y la adversidad, gracias a dones privilegiados para la resistencia y el sacrificio, lo que conduce a la reformulación de los pactos sociales. El héroe, de esa manera, se transforma en una metáfora del ser masculino kawésqar, obteniendo por ello, prestigio comunitario.

PALABRAS CLAVE: Lenguas fueguinas, kawésqar, literatura oral kawésqar, mitos kawésqar, cuentos kawésqar, narrativa.

\section{THREE HEROES IN THE KAWESQAR MYTHICAL WORLD}

\begin{abstract}
In this article my aim is to study the specificity of the role of the hero in two Kawésqar stories: the Tale of Annapas and the Tale of the mouse. From the reading and analysis of oral texts of this ethnic group from southern Chile, I hold that heroism, similarly linked to male character has a unique and differentiated existence, which manifests itself in the first case, through a rhetoric of actions linked to the confrontation and power and, in the second example, neglect and overcoming adversity, thanks to privileged gifts for resistance and sacrifice, which leads to the reformulation of social pacts. The hero, thus, becomes a metaphor of being male Kawésqar, obtaining therefore community prestige.

KEY WORDS: Fueguian languages, Kawesqar, Kawesqar oral literature, Kawesqar myths, Kawesqar stories, narrative.

1 Este trabajo se desarrolla en el marco del Proyecto Foncecyt No. 1100334, titulado: "La narrativa de mitos en la literatura kawésqar, un enfoque a través del análisis del discurso y de la literatura".

Ph.D. en Literatura Chilena e Hispanoamericana. Universidad de Chile, Depto. de Teoría e Historia de las Artes, Facultad de Artes. eugeniabrito@hotmail.com.
\end{abstract}




\section{INTRODUCCIÓN}

El presente trabajo se basa en parte del corpus de textos orales recolectados por Oscar Aguilera y José Tonko entre 2006 y 2007, en el marco del rescate de la lengua y cultura kawésqar, que ha conocido diferentes publicaciones, a través de libros, artículos y ensayos distribuidos tanto en Chile como en el extranjero.

Entiendo esos textos como escritura productiva del pensamiento kawésqar que, como tales, encuentran en el relato la forma política y cultural de elaborar, con actantes distintos y en diferentes espacios y tiempos, los relatos que dan sentido a la vida del grupo a la par que de proveer los modos en que se organiza su cultura y los destinos históricos de sus integrantes.

Para decirlo de una manera simple, los textos son signos de una frase múltiple que recorre la historia de un motivo o de una forma cuyo sentido o función se inserta como una variable dentro de la malla estereográfica que conforma la totalidad. Totalidad también incierta pero que comparece en el fragmento, en el recuerdo de una anterior enunciación realizada en otro contexto histórico, según el cual el relato se comporta como cita de un tiempo previo. Jacques Lacan (1975), el gran psicoanalista que ha señalado que la escritura del inconsciente es análoga a la de la letra, ha dicho también que éste es señalado en la vida psíquica del hombre como el capítulo censurado, muchas veces marcado por el blanco o bien, ocupado por el embuste. La verdad puede estar escrita en otra parte: en los monumentos, que son el cuerpo en que se manifiesta la cultura, donde en muchos casos el síntoma histérico muestra la estructura de un lenguaje y se descifra como una inscripción; en los documentos de archivos también, que emergen en los recuerdos de infancia, impenetrables tanto como ellos; en la evolución semántica de ese lenguaje, que se corresponde con el estilo de la vida y el carácter; en la tradición y en las leyendas que vehiculan la historia, en los rastros.

Pero es imposible una enunciación que parta de una "verdad" a priori, como un dogma: un acuerdo de la letra con su referente es imposible; se trata siempre de la ficción del relato, eso es lo verdadero de esta poética así como de otras.

De esta forma, la escritura de un pueblo, un grupo social y su desglosé está contenida en estos textos tanto en lo que dice, como en lo que calla, en el silencio, el olvido, o en la desconexión. En la vacilación, en el desplazamiento hay tanta elocuencia como en los relatos; ese lugar paradojal constituye el espacio de su enunciación. Puesto que se sabe desde Benveniste (1977), que es la enunciación la que pone en escena un significante que se desplaza y condensa en metonimias y metáforas, los ejes paradigmáticos y sintagmáticos del lenguaje.

Tal como lo desarrollara después el gran lingüista de origen ruso, Roman Jakobson (1970), el lugar de éste es el no-lugar; ya que el significante se escapa cuando se lo creía tener; pero su fuga imprime una dirección, un impulso que orienta toda la vida síquica.

¿Cómo captamos la escritura de la historia de un grupo cuando éste está representado por una gran ausencia, un motor vacío, del cual nos llegan los ecos? Se pensaría que ella está conectada con una imaginación mítica, vivida en el interior de las sociedades humanas, en medio de las cuales los hombres se piensan y se experimentan como seres diferenciados de la naturaleza, por lo cual se erigen según Vico (1995) en regla del Universo. De este modo, se otorgan las figuras totémicas o metafóricas que los representan, o que manifiestan características deseadas a la par que señalan las relaciones que explicitan las maneras de vivir el mundo de una comunidad.

El imaginario kawésqar lo es de sobrevivientes marinos respetuosos de un sistema de creencias de las que intuimos algunas. Sus saberes son poderes que les permiten producir una comunidad, compuesta de grupos diversos, pero que están unidas por la producción de un simbólico, que se materializa en un archivo de las ideas, emociones, pensamientos de un hombre en una comunidad.

Entonces, este archivo kawésqar nos habla de un grupo, hoy diseminado, que da cuenta de cómo una comunidad se entiende a sí misma en el concierto de otras comunidades. El trabajo de la etnolingüística tiene hoy, lo vemos, una opción política: el rescate de las formas de vida y la concepción de mundo que emana de dichas formas.

Los relatos orales tienen como sentido elaborar una práctica de la memoria, práctica que mantiene vivos los nexos históricos de una comunidad, rica en motivos, como lo revelan estos textos orales. Su función es la articulación de la vida de una co- 
munidad. Comunidad imaginada, a través de estos relatos, espacio practicado a través del trabajo y de las prácticas de vida en grupo.

La vacilación forma parte de este sistema de escritura, como podemos apreciar en la relación que hace el narrador Francisco Arroyo, a la que nos referiremos más adelante. Es el origen diferido, la marca de la negación del sentido aplazado y refractado, no lleno, sino que pulsado en un segundo tiempo: el de la palabra, que evoca la escena originaria, sabiendo que tal vez no hubo una primera partitura, que tal vez la frase mayor, de ese texto sea la consecuencia de otra, que se borró, con la muerte del narrador ejemplar, o quizá no existió y si lo hizo tuvo dudas como él, y que lo que la etnolingüística pone en cuestión es el "gran texto, repleto de verdad, al modo de una gran ley que no fracture su decir".

En eso consiste su contemporaneidad. Lo que ocurre con los kawésqar es el quiebre de la representación única, la creencia en ella y en el poder de su infranqueable razón, de su verdad.

Hay pues, en cambio muchas verdades en estos mitos y en sus complejas narraciones. Hay muchos sentidos detrás de la dirección que los significantes materiales enuncian.

\section{METODOLOGÍA}

Ocupamos el postestructuralismo y su concepción del texto como un conjunto de relaciones cuyo tramado se lee de acuerdo al valor y sentido de cada signo así como de la lectura de la totalidad. En esa dirección, hemos incorporado a Roland Barthes (1970; 1975).

Dentro de los análisis mismos, tratamos de tomar la dirección del Significante, como vehículo que orienta y vehicula la dirección del texto. Por cierto, como ya habíamos señalados, nos movemos con Lacan y con Derrida (1975), en sus consideraciones sobre el lenguaje y el pensamiento, específicamente, cuando señala que el lenguaje siempre es diferido, retardatario con respecto a un posible "inicio".

También, consideramos las importantes consideraciones de Jakobson sobre las operaciones del lenguaje, sabiendo que él está a la base de Barthes en su tratamiento de la retórica como una función del discurso que consiste en hacerse cargo de la disposición del lenguaje con miras a suscitar la atención del otro. Esta distinción emanada del saber griego, particularmente de Aristóteles, ha sido reevaluada por el postestructuralismo, como un nivel de discurso fundamental y que requiere de nuevas revisiones, como espacio que llega desde la subjetividad de un autor a un grupo cultural, como receptor deseado.

En cuanto a los niveles del discurso, nos son familiares los aportes de Julien Greimas (1971), así como también las caracterizaciones de este discurso por Gérard Genette (1971). Desde los estudios de la antropología es señero Claude Lévi- Strauss (2006; 1986a; 1986b).

\section{EL CUENTO DE ANNÁPAS}

Uno de los relatos que analizaré será el "Cuento de Annápas”, narrado por Francisco Arroyo Sotomayor, uno de los narradores tradicionales que ha desarrollado un rol de emisor y reconstructor de la ficción de la memoria y cultura kawésqar.

$\mathrm{Su}$ texto es rico en figuras literarias en una narración que es muy precisa en la localización geográfica a la vez que tiene una enunciación muy libre del tiempo y del espacio, lo que quiere decir que hace referencia al pasado y luego vuelve al presente, dándole volumen y espesor a la textualidad que registra y conforma. En este ir y venir entre dos tiempos, se efectúa el núcleo performático de la narración; el mundo imaginario se reconstruye con el testimonio biográfico del narrador, realzando la unidad de los tiempos, en un esfuerzo por darle credibilidad a los acontecimientos narrados.

El texto en la transcripción y traducción de Aguilera-Tonko (2011) consta de 251 segmentos, que resumo a continuación:

Annápas habita el sector denominado Sojérpe, que corresponde a Barros Luco en el archipiélago de Madre de Dios, en la cartografía oficial (01). Era custodio de nidos de albatros situados en lo alto de un barranco, fuente de alimento para su grupo (02-07). El sitio es real y el narrador ha navegado por ese paraje (08-11); también por allí navegaban los antiguos kawésqar, quienes conocían muy bien esa zona (12-34). Annápas defendía enérgicamente los nidos de albatros de los intrusos que podrían llegar y despojar del alimento a los suyos (35-37). Descubre que alguien había cazado unos pichones, habiendo subido a lo alto del barranco por una red. $\mathrm{Al}$ sorprender al intruso, corta la red cuando éste se 
encontraba a medio camino, con lo cual cae sobre las rocas de caliza quedando malherido (38-40). El intruso es Aterrájes, concuñado de Annápas, quien había viajado desde su territorio a visitar a su hermana (41-43). El marido de su hermana ve cuando cae y le presta ayuda y lo oculta (44-52), puesto que Annápas era muy belicoso y no permitiría que el intruso quedara con vida (53-56). Al día siguiente, antes del amanecer, la hermana de Aterrájes va con una canoa al lugar donde se escondía éste, lo hace embarcar y lo oculta en su canoa cubriéndolo con cueros de lobo, para llevarlo a otro sitio más seguro (57-59). Aterrájes se oculta en la espesura y observa a Annápas que está en lo alto, en la turbera, desde donde podía cubrir gran distancia con la vista, intentando descubrir dónde podría estar Aterrájes. Posteriormente Annápas expresa sus sospechas respecto al paradero del intruso y pasa más tiempo en la carpa de su hermano que en la suya, donde se encuentra la hermana de Aterrájes (60-62). Por recomendación de su hermana, Aterrájes debe irse del territorio de Annápas y zarpar hacia Jeqanái-herrétqal (San Eduardo). Antes del amanecer, toma una canoa del campamento de Annápas, probablemente la de su hermana, no sin antes dañar los remos de las canoas de Annápas y sus compañeros, los cuales debilita en la parte de nudos de la madera. Cuando Annápas descubre que una canoa salía de su puerto rumbo a la mitad del canal, se embarca en su canoa con otros remeros para perseguirla y destrozarla; sin embargo, al remar vigorosamente los remos se rompen donde estaban los nudos, sin poder salir del puerto. En tanto, desde la distancia, Aterrájes señala con su dedo a su atacante y exclama: "He aquí la marca que me dejaste" (63-76). Aterrájes sigue su viaje y llega a su territorio. En tiempo de huevos sale a recolectar y llega a la playa que se conocerá posteriormente con el nombre de Aterrájes-afsáqta-jerás ("[Donde la canoa de] Aterrájes quedó en seco por efecto de la bajamar"). Deja su canoa en la playa, va a buscar huevos y cuando vuelve no puede poner a flote su canoa por la bajamar. Por más que lo intenta, no puede $y$, finalmente la canoa se convierte en roca. Aterrájes queda náufrago en esa isla y nadie sabe qué pasó con él, tal vez se transformó en piedra o en árbol. (77-112). El narrador describe el lugar en la actualidad (113-116) y luego hace una recapitulación del cuento y describe los lugares donde suceden los eventos según su experiencia después de haber estado en ellos (117-164). Retomando la narración, cuenta que al territorio de Annápas llegan jotes que asesinan a sus coterráneos, raptan a su hija y a su sobrina. De la matanza escapan algunos con vida y con uno de ellos parte Annápas en persecusión de los jotes (165-175). La hija de Annápas en su desesperación y luego de haberse caído en una playa en el canal Octubre, se transforma en piedra (177-182). Annápas encuentra a los jotes y los mata, pero sólo puede rescatar a su sobrina con vida y regresa a su territorio (183-251).

El primer dato entregado por el narrador es el de la localización geográfica: la precisión del lugar en el cuento es importante ya que ancla y fija la memoria, permitiendo un mayor enriquecimiento de la materia narrada y de sus sentidos culturales:

Annápas jenak-qei-so-hojok sa Sojérpe, Barros Luco kiaraháker pe kius jénak-qei-so-hójok eik'uaháker hójok. ${ }^{3}$

En Sojerpe estaba Annápas y [ahora] le dicen Barros Luco, ahí estuvo se cuenta.

(Aguilera-Tonko: 2011. 3, § 1)

El cuento de Annápas se desarrolla en una relación de rivalidad por el lugar masculino dominante. Desde los inicios, él observa a Aterrájes como un "intruso", un extraño, que, a pesar de la liberalidad propia de los kawésqar, llega al cerro que él cuida, sube por la soga que él ha implementado y toma los pichones que Annápas quiere y cuida para sí y los suyos. Es una clásica disputa por el "territorio propio", en que el poder lo tiene el primero, porque es más fuerte y porque ha asentado un mayor dominio que el segundo por ser el que ayudado a hacer más próspera la vida del grupo; tiene allí su familia (hija) y su carpa.

En otra dirección, complementaria con las que se mencionan aquí, puede verse este episodio, como el conflicto con el "doble", el que integra aspectos no deseados del yo, apareciendo como el otro, desamado, rechazado.

Lacan ha estudiado en su libro La Familia (1987), este doble como parte del complejo psíquico del "hermano", vivido por el niño en tempranas etapas de su vida, como una instancia previa al Edipo,

3 En los ejemplos en kawésqar se utiliza el Alfabeto Estándar de la Lengua Kawésqar. 
y que supone la difícil coexistencia con el otro, el niño/niña que cruza su espacio íntimo y moviliza su subjetividad volcada hasta entonces en la madre $y$ en la necesidad del dominio de las coordenadas témporoespaciales.

La relación entre ambos puede verse como un antagonismo entre un yo y su otro, entre dos hombres en que uno tiene un poder más legitimado que el rival, y en que ese poder se ejerce con agresividad.

El recurso literario más importante del texto es la metonimia, cuya acción estructura el cuento como proceso de significación a tal extremo que podríamos decir que todo el cuento se estructura en todos sus niveles por los cortes y recortes de un cuerpo que se presenta siempre en relación con otro, al que odia, atisba, enuncia, daña y del que se tienen nociones que hacen presumir una contienda previa, en el orden simbólico, (el Doble y el Edipo del que el texto da cuenta) ya que lo que finalmente viene a estar en juego es la noción del ser y de la frontera del ser, amenazado desde un principio por esta preeminencia de otro que lo retiene y lo devuelve en una estructura incompleta y neurótica.

Aterrájes viene desde otro lugar, a visitar a su hermana. El motivo del obsequio lo lleva a cazar los pichones, lo que significa para Annápas, la "infracción" a su ley; ése es su cerro, sin embargo, Aterrájes debe cumplir la promesa de obsequio, propia de la hospitalidad. Esa es la paradoja del texto: Aterrájes no puede irrumpir en el coto de caza, pero debe cumplir esas normas sacras que lo llevan a la infracción de la ley. Eso le trae la expulsión, cae derrotado a la piedra caliza.

Su cuñado lo observa, le presta ayuda y la soga vuelve a caer para Aterrájes. Sube por ella y su cuñado lo oculta, pero ha de irse a la mañana siguiente. Y aquí se formula el otro núcleo complejo de significación del relato: la relación tanto de Annápas y de Aterrájes con la pareja de dos hermanos de ambos casados y que constituyen un espejo de las pulsiones destructivas de ambos.

La pareja es el lugar de la igualdad (está constituido por seres con la misma sangre de los héroes) y la diferencia (el matrimonio une gentes de diferente sexo); la pareja pone de manifiesto fuerzas antitéticas de correlación grupal, pues muestra que bajo la alianza conyugal ambas familias pueden unirse. La pareja es la unidad sociosimbólica que garantiza la posibilidad de unión de ambos, pero a la vez también, esta pareja está vetada para Aterrájes, por Annápas. La visita misma se demuestra como imposible.

¿Por qué? Porque la figura que atrae al lugar a Aterrájes es la hermana. De ahí la fuerza deslizante y misteriosa del texto. Esta hermana que lo ve desde que llega y que surge desde el cuento como un don imposible de tener (de visitar) para Aterrájes. La visita cuenta desde el principio con el veto de Annápas, cuyo poder se transfiere al hermano y que le hace saber que no pueden recibirlo por mucho tiempo. Es un infractor y sobre él pesa una condena: la expulsión que Annápas le ha preparado y que significa el retorno a su lugar. Aterrájes no es una visita recibida con agrado. Su hermana le avisa que debe retirarse.

La ayuda ya tiene un precio: el límite. Sólo por una noche, el héroe oponente puede quedarse con la hermana, al otro día, debe huir, esconderse, ya que la pareja tendría problemas con Annápas. Es decir, la acción de Aterrájes, su alteración del código cultural de la "propiedad legítima", su incumplimiento ayuda a formular la legitimidad de la autoridad de su rival, y le señala además una condena: está expulsado del grupo, pese a que tiene allí a su hermana y que él sólo deseaba cumplir la norma de los dones: el regalo esperable de una visita.

No obstante, nada de eso parece funcionar, la pareja lo ayuda a irse a un sitio en el que pueda esconderse y pernoctar esa noche, pero de mañana temprano, debe irse.

Cuando se va, cruzando el mar, los ojos de Annápas lo miran. Ojo contra cuerpo, los dos hombres se encuentran; uno desde el cerro (posición superior y segura); el otro desde el mar, (escenario de grandes batallas) huyendo de mañana, tratando de no ser visto. Así conforman la relación de perseguido y perseguidor; función complementaria. A su vez, éste es el único momento en que Annápas divisa íntegramente a Aterrájes. El resto son acciones, consecuencias de un hecho capital; pistas inconclusas. Aterrájes para él era casi un presentimiento, es decir, más que nada una huella.

Nótese también que la relación de la hermana marca a Aterrájes con el polo femenino: hermana; polo inferior, femenino, semióticamente más débil.

En la cultura kawésqar, además, la mujer casada debe más obediencia al lazo conyugal que al parental. El "marido" pesa más en sus decisiones que 
el hermano, lo que significa que incide más Annápas sobre la pareja de "hermanos" que Aterrájes, y que vuelve el primero a ejercer el poder sobre el segundo. La pareja no puede recibir al hermano herido; su carpa es muy cercana al poderoso Annápas, quien sabiendo de la proximidad de su otro, vigila y controla su presencia en la carpa a la que llama "carpa de Aterrájes". De esta manera el cuento resalta el poder del dominador y la debilidad de Aterrájes.

Sin embargo, la existencia de la hermana agrega una connotación más fuerte: y que dice relación con la pulsión incestuosa. Para decirlo de otra manera, es por esa hermana que él, Aterrájes ingresa, al campamento de Annápas, como se puede también denominar la isla:

[Aterrájes] "Annápas at kar" ak'uás kiarseketálæer kar sa kuósos aqájeks-hójok eik'osekčéjer-hójok.

[Aterrájes] había zarpado a remo de una isla que se llamaba "el campamento de Annápas," se cuenta.

(Aguilera-Tonko 2011: 13, §64)

Ella es el regalo precioso y esquivo para quien van los pichones cazados y el riesgo del viaje. Ella es la fuerza que estructura una prohibición; ya casada, ella pertenece al mundo de Annápas: está bajo otra ley, no disponible para él, el Edipo la requiere como prohibición, y esa orden tajante la mantiene Annápas.

La atracción entre ambos determina el texto; pues al llegar a la isla; él piensa en ella; al caerse él, es el marido, hermano de Annápas el que primero lo hace salir (cumple la ley del grupo, la ley del Padre, de Annápas: su ley). Por algo es el hermano.

Afirmamos entonces que Aterrájes enuncia el cuerpo de un deseo incestuoso, trasgresor, que viene a poner de manifiesto el terror del inconsciente tribal, que exige la mantención de la ley de Edipo. De acuerdo a esta ley, Annápas se enuncia a sí mismo como el Padre simbólico del grupo; es el conocimiento de una modalidad cultural estructurante de la vida en comunidad de donde extrae su fuerza. Pues el incesto es la pulsión desde la cual se organizan los grupos sociales y las reglas específicas de ordenación tribal. La familia, el parentesco, la economía, y las relaciones de producción se estructuran desde el terror a infringir esa ley parental. El tabú del incesto es la más antigua prohibición que pesa sobre el hombre. Aterrájes va a ver a su hermana: un ojo lo observa desde lo alto, una fuerza que impide la visita.
Por ello, la pareja de la hermana de Aterrájes y hermano de Annápas (figuras que son ambas metonimias de dos poderes), intentan borrar el cuerpo de Aterrájes de la escena; por ello, se lo recibe sólo una noche, luego lo obligan a partir de mañana, disimulando su cuerpo, intentando camuflar su naturaleza humana, por eso va escondido con cueros de lobos y pasto. Esta huida marca su condición de exiliado con respecto a Annápas y la debilidad del lazo filial con su grupo próximo, en el como ya se dijo, domina el primero.

Esta separación del poder central establece un cuerpo y una historia como subalterna a la par que establece la fuerza de la voz del padre, por sobre la de la madre; Aterrájes es un cuerpo que, condenado por el grupo, es sentenciado a morir: pasa desde el disimulo (inexistencia física) al exilio (inexistencia simbólica y formalización de la categoría subalterna de "extranjero") y desde allí a la petrificación, (inexistencia ya como vida; formalización de inexistencia vital, el héroe deja de existir).

De modo que el cambio de Aterrájes es rápido, desde la caída, se hace imposible tanto la permanencia en el lugar como el regreso a su hogar se hace difícil: Annápas sólo quiere su muerte y por ello, cuando mira desde lo alto la canoa, piensa en destruirla:

Kuosá háute kuosáp hápar kájef akiár čečél jeksór-hójok kuterré akér kekiása eik'olájer kuosá ku čejek'éna ka kuteké aqájeks kuteké kenčátauk kekiás kuos.

Cuando [Annápas] observó que una canoa estaba cruzando hacia al frente por la inmensidad del mar, se cuenta que inmediatamente regresó corriendo [al campamento] con la intención de ir a perseguirla a remo y remar a toda fuerza y hundirla partiéndola con un hacha, [por eso bajó] corriendo.

(Aguilera-Tonko 2011: 15, §72)

Y aquí vemos la canoa como metonimia del héroe no querido, es decir, Aterrájes, la mención del navío aparece sustituyéndolo (pars pro toto): la canoa es el hombre. Para el pueblo kawésqar por su cultura y sus hábitos de vida, esto es prácticamente así: un hombre es su embarcación, con ella viaja, en ella "vive" por meses (aunque no pernocta en ella), en ella pesca.

De hogar, la carpa del hermano de Annápas, se convierte también en sitio de observación, en 
lugar estratégico de producción de signo: observación, deseo, escape. A "la carpa de la hermana", en donde cuenta que Annápas permanecía más tiempo". Es decir, el sitio de la carpa es también un espacio controlado por Annápas sabiendo el lazo de parentesco que su cuñada tiene con Aterrájes:

Kuosá háuk sa at-terré akér kuos kius at kuos Aterrájes ak'uás kiarlái-s kuos kius askét... taksóktek-sélas at kuos ku at kuos atótæel-hójok eik'olájer-s kuos.

Contigua a la carpa [de Annápas] estaba la carpa de la hermana del que llaman Aterrájes, en esa carpa se cuenta [que Annápas] permanecía más tiempo.

(Aguilera-Tonko 2011: 13, §61)

La isla misma llega a recibir el nombre de "campamento de Annápas", lo que el narrador entrega como dato en $\S 64$, y que dato feliz a la memoria, viene recién a comparecer en ese punto, cuando el exilio es la clave de la condena explícita que sufre Aterrájes:

Kuósos sa kuos Jeqanái-herré-tqal ak’uá San Eduardo kiarahák tqal hápar aqás-ker eik'olái-s kuos kuósos aqájeks, "Annápas at kar" ak’uás kiarseketálær kar sa kuósos aqájeks-hójok eik'osekčéjer-hójok.

Después de eso [Aterrájes] se fue navegando a remo a Jeqanái-herré-tqal, lugar que se llama San Eduardo, se fue remando, había zarpado de una isla que se llamaba "el campamento de Annápas," se cuenta.

(Aguilera-Tonko 2011: 153 §63-64)

Es importante destacar la línea férrea de exclusión ejercida por Annápas sobre Aterrájes, que parte desde lo más visible (el coto de caza) hasta totalidades más abstractas: pernoctar en la isla; la visión de su contendor navegando de retorno a su hogar, siempre el poder, representado por el dedo, como gesto de una deixis condenatoria y determinante se mantiene erguido: el dedo de Aterrájes señala a su opositor, enunciado la ley:

Kuosá Aterrájes ak'uás aselájer-s kuos jetó... jetalái-ker aselái kuteké ječerlájer kuos, kuosá jetésosektálæer: "Hannó jetáksta-ar."

Se dice que Aterrájes estaba molesto y señaló con el dedo a su atacante y dijo: "He aquí la marca que me dejaste."

(Aguilera-Tonko 2011: 16, § 75-76)
Pero al fin, Aterrájes, vencido, se va a remo a Jeqanái-herrétqal, (San Eduardo), en donde permanece y donde se queda a vivir para siempre. Llega y va a buscar alimento, y cuando retorna, con pichones y huevos en sus manos; la canoa que había dejado, estaba en seco, por efecto de la marea baja. Trata de moverla y no puede; la mueve, piensa en buscar ayuda, pero ella se hace no sólo pesada, sino pétrea. Es decir, se vuelve roca.

La canoa se hace signo del cuerpo deprimido de Aterrájes, quien, de modo consecuente y progresivo con el relato gradualmente se vuelve también piedra, es decir, retoma su condición de naturaleza, con la que el cuento lo castiga:

Kuteké k'iesáuna kuteké kárna, eik'olái k'élok hójok sa kuos Aterrájes kuos eik’olájer-s kuo.

Y se convirtió en piedra o en árbol, eso no lo contaban cuando contaban el cuento de Aterrájes.

(Aguilera-Tonko 2011: 21, § 110)

Pero, una última prueba sobreviene a Annápas y ésta se ejerce sobre su grupo familiar y social, particularmente, sobre su hija y su sobrina.

Esta ocurre un día en que llegan a su isla jotes asesinos ${ }^{4}$ que matan gran parte de sus coterráneos y se llevan a su hija y a su sobrina.

Dos mujeres, de manera correlativa a los dos hombres; dos mujeres son botín de guerra. Annápas lo sabe por las señales que le mandan los que sobrevivieron al ataque. Busca a los agresores y cuando los encuentra, los mata. No obstante su hija se ha convertido en piedra; se ha resbalado y caído con las rodillas dobladas; es allí cuando se vuelve piedra, experimentando así una pena similar a Aterrájes.

4 Los hombres-animales en los mitos kawésqar “... son hombres cuya forma física es igual a la de los hombres comunes, pero cuyo os (alma) es animal. Al morir un hombre-animal se transforma en un animal y su os permanece en el mundo de los vivos en un nuevo cuerpo, pero cuando un "hombrehombre" muere, su os se va a hóuk'a álowe más allá del horizonte. Se puede decir que el hombre-animal renace en otra forma, en tanto que el "hombre-hombre" no. Ambos perecen como hombres, pero sus os tienen un destino diferente, aunque ambos al dejar de ser hombres igualmente se sumen en el olvido. El hombre-animal al transformarse en animal no puede recordar su vida de hombre, el hombrehombre no puede recordar su pasado, es un espíritu que va a morar a ese lugar más allá del horizonte repitiendo su forma de vida, sin saber de la existencia que tuvo antes ni a quien dejó tras sí." Oscar E. Aguilera F. 2011, "Relaciones con el mundo real en los relatos de mitos kawésqar", MS. 
Correlativamente, ambos hombres sufren y pierden. Uno, su canoa y su posibilidad de vida, puesto que sin la canoa no puede abandonar el lugar donde ha quedado y no puede obtener alimento; el otro, su hija y su descendencia por el lado femenino. Más aún ella se convierte en una estatua que recuerda continuamente la historia, la hija se queda como dato mnemónico kawésqar.

Es interesante observar la concepción genérica kawésqar, en que la mujer como en muchos grupos humanos, cristaliza una tensión, representando un área sensible involucrada en la emotividad y en la concepción de la "pena ". Cuando se trata de desarrollar un conflicto, la presencia de la mujer anuncia y avisa la catástrofe. Primero, la hermana, y, desde ella, por su posición en la familia, su capacidad para remover en los hombres la noción de "propiedad", "confín", "frontera" y "territorio" que cruza las aguas y que orienta en el imaginario kawésqar tan nómade el valor de la casa y desata por ello, la importancia de la relación de pareja y el matrimonio, en que la tensión (sexual y social) parece encontrar calma y organización, sublimando un poco el Edipo.

La hija es la figura de la mujer joven, en la que los jotes dañan a Annápas, cuestión que comparte con otros textos de sagas heroicas, ni más ni menos que con El Cid Campeador. Bástenos recordar la alianza de Corpes, que de manera más refinada, da cuenta de una venganza política sobre el héroe, ejercida en las hijas. La concepción cristiana modifica y determina un desenlace más calmo y proclive al $\mathrm{Cid}$, pero de todas maneras ellas sufren un abandono en una zona solitaria y su encuentro determina la necesidad de reparación.

Pero en el texto en análisis, la hija queda de esta manera integrada como piedra al paisaje, demostrando la fatalidad de la condición humana, en sí misma, ambiciosa y guerrera; ella, víctima de la opresión de género muere y su historia la recuerda como fin de la saga guerrera.

\section{EL CUENTO DEL RATÓN}

Este texto y sus variantes ${ }^{5}$ igualmente pertenece al Archivo Sonoro de la Lengua Kawésqar,

5 Variantes de este cuento se encuentran publicadas en Aguilera-Tonko. 2009: 29-33, en las versiones de los narradores José López y Francisco Sotomayor. elaborado por Oscar Aguilera y José Tonko, cuyo resumen es como sigue:

El ratón vive en la isla llamada Aqálker-atáwer, de torrentosos vientos. Ha quedado abandonado de pequeño, debido a una invasión sálam, grupo kawésqar del norte, que dio muerte a su padre y a su tío paterno. Su madre fue raptada, sin embargo logra ocultar a su hijo pequeño antes de que se la lleven. El ratón se cría en extrema orfandad y desarrolla habilidades de caza y pesca, así como también se hace un experto en dotes culturales, como en la preservación de alimentos y en la confección de flechas. También desarrolla habilidades como proveedor de alimentos: caza lobos marinos, toninas y pájaros a la vez que pesca y marisca. Sus dos características más importantes son su sabiduría y su velocidad, las que, junto a su capacidad de mutación entre hombre y ratón, le otorgan la investidura del héroe. Gracias a ella, combate a los sæélam, que llegan en numerosos grupos, a matarlo, hasta que su madre identifica la huella del hijo en el guerrero y va, junto a su hermano menor, en una embarcación para buscarlo y reorganizar un reencuentro. Así se formaliza la paz y el héroe reorganiza el pacto social, afirmándose como figura de poder y respeto en el grupo.

Este cuento se desarrolla sobre la base de la creencia kawésqar de que existe un continuum entre hombres y animales. Hay hombres animales y hombres pájaros, (cf. Aguilera-Tonko, 2009: 14 y Aguilera, 2011, MS). El ratón, por ejemplo, es un hombre y un ratón, por ello, posee la facultad de aumentar y/o disminuir su estatura.

El primer motivo que cruza el cuento del Ratón es el abandono y la separación del poder jerárquicamente mayor, lo que concuerda con la mitología heroica de Occidente, en la cual, Aquiles (La Iliada) y El Cid (El Cid Campeador) se separan o los separan de un poder central, que se considera injusto, incapaz de detentar de manera sabia el mando del grupo o de los grupos sociales que constituyen la comunidad. El exilio del Ratón es complejo, en la medida en que sus enemigos (los sálam) lo persiguen infructuosamente para matarlo y obligan al ratón a investirse bélicamente, es decir, a enfrentar el mundo de la guerra usando su astucia, su velocidad y su capacidad de transformación.

El segundo motivo que cruza el texto es la investidura del héroe: hay tres factores que se destacan en la construcción del carácter heroico del ratón: la 
astucia, unida a la capacidad de observación de los desplazamientos de sus enemigos y su velocidad, la que le permite hacerse pequeño y efectuar maniobras rápidas, sea subiéndose a los hombros o a la cabeza de sus enemigos para hacerlos sucumbir gracias a sus propios garrotazos. De esta manera, logra ser invencible:

Ak'uás kuerkuás akiár asó kius kučelákaso kaftálqar táwon asó kuo aksépče astálp aksépče kuos eikuákiar-k'ejeháker kuo. Kuosá kuos kius jetás ka kuteké kius kučelákso ktep čečáu-eikuáqas-k’enák ko jeksór kuo aksárrok kius kučelákso ktep atqásap Sálam-s káwes kuteké takuónkar hápar kekétqak'enák eik'olájer-s kuo. Kius aksárro ka kuteké kius kučelákso kuteké... kius qar léjes jetzel kius kučelákso kučelák aqačál so kuo eikuákiar jetás kuo.

[El Sálam] había lanzado [el golpe de su garrote] blandiéndolo [con fuerza] y éste llegó a la cabeza de su compañero la que un momento antes [el ratón] había abandonado de un salto y [de esa manera los Sźlam ] siempre mataban [a sus propios compañeros]. [El ratón] al ver [que los Szélam] eliminaban a sus compañeros, que se mataban a garrotazos unos a otros, para engañar a sus compañeros, el ratón siempre subía corriendo al cuerpo de los Szélam, al hombro, se cuenta. Su engaño era para que los [Szélam] matasen a sus compañeros, a los que habían llegado navegando a remo juntos, esta treta era para que se mataran a garrotazos.

(Aguilera-Tonko, 2010-2011: 36, §§ 229-232)

El ratón une a su velocidad física la rapidez mental: una flecha cae en su carpa y él ve el signo de la confrontación. Es una flecha mayor de las que él fabrica. Sus perseguidores intentan derribarlo, pero no pueden, no obstante, siempre de manera abrumadora, persisten en el conflicto:

Kiáno jetanák kúkstai ak’uás kius ksečép atzel kstái ka kius jetaqána tóu Szélam-s jetaqána kuos čet.... Kokiúk jerfčal akstáp-k'éna aksó-k'éna ačéjer askét... p'áp'e kstáik c'áfes tqal kstaik.

He aquí que [mientras] estaba trabajando cerca de él [cayó] una flecha distinta a las suyas, una flecha de los Sźlam. Allí a ese lugar llegó velozmente [la flecha], se clavó y penetró en el barro, en el líquen.

(Aguilera-Tonko, 2010-2011: 11, §§ 60-61)
El cuerpo del ratón se extiende, metonímicamente, a sus pequeñas flechas ${ }^{6} \mathrm{y}$ al garrote como instrumentos de lucha, armadura de guerrero que se adecua a su capacidad de empequeñecerse $\mathrm{y} / \mathrm{o}$ agrandarse.

El cuento juega con la visibilidad y la invisibilidad, propias de un subalterno, según los teóricos del colonialismo y la crítica cultural, Gayatri Spivak (1985) y Homi Bhabha (1994). Un subalterno es quien depende política y culturalmente de una cultura, de un orden político y, por lo tanto, de las instituciones, las creencias y el sistema de vida de quienes detentan el poder.

Aplico estos conceptos al Cuento del Ratón por tratarse de un relato en que se juega la salida de una situación de desventaja y de frecuentes persecuciones de grupos más numerosos que él y, más avezados en el arte de la lucha. De manera analógica, la historia es alegórica de la situación de los kawésqar en los mares del Sur y, podemos extender la actitud de los Sźlam, a la de los occidentales, los blancos, de origen europeo; en todo caso, el ratón debe sortear el desamparo, la soledad y todo esto lo hace porque "creció y se hizo sabio", como dice el narrador:

... kuosó eik'óse arhanána kuteké os-ksæerzérna. hizo sabio.

... y después, según el cuento, creció y se

(Aguilera-Tonko, 2010-2011: 5, § 14)

Sabio para entender que el único especio de interlocución es el cuerpo y la acción, por ello, el cuerpo es el que se oculta y se ve, se muta, sube por los hombros y la cabeza de los enemigos, los mata a garrotazos o hace que se maten a sí mismos, arrancando velozmente de los golpes con los que pretenden herirlo.

Cuando el ratón sale de la espesura, en la que se esconde y con la que se mimetiza, el narrador señala:

... kuosó čečáu-jerqolókna asó zértqa kuteké jenák-hójok eik'uaháker-hójok kuos.

... después el ratón se hizo visible y además creció, se cuenta.

(Aguilera-Tonko, 2010-2011: 4, § 8)

6 Kius jetaqána sa jek'éwot hójok eik'osekčéjer-hójok kar árret-jeké ak'uás jek'éwot ciprés árret-jeké so.

Sus flechas eran pequeñas, se cuenta, eran varitas pequeñas, eran varitas de ciprés.

(Aguilera-Tonko, 2010-2011: 7, §§ 28) 
Esta visibilidad o invisibilidad, mencionada como dato importante por el narrador, se relaciona según el teórico del colonialismo, Homi Bhabha (1994), con la capacidad subalterna de circular sin ser visto, desafiando la presencia del Yo del dominante.

Sabe que la mirada del poderoso lo convierte en un reducido estereotipo, un fetiche en el que se encarna el otro. El Ratón sabe que lo encuentran pequeño, pero con la memoria viva de la muerte de su padre y de su tío materno, sabe que esperaban que él hubiera muerto de indefensión y que por ello, lo buscan, queriendo acabar con él y de ahí que recurra a la invisibilidad.

Existe una "compleja duplicación de tiempo y espacio como el sitio de la enunciación y la condicionalidad temporal del discurso social" (Bhabha, op. cit.: 77). El ratón trabaja con una noción plural del tiempo y la historia, frustrando la operación del sentido "común" de sus atacantes. Esa es la emoción y la amenaza que hace temblar el desarrollo de la lógica narrativa del cuento, volviéndolo paradigmático no sólo del pasado mítico sino también del mundo contemporáneo en que el ratón traza las huellas de un héroe posmoderno y poscolonial, que sobrevive gracias al arte de la alusión y la elusión frente al poder que lo confronta y amenaza con destruirlo. "El ojo maligno, que busca mirar fijamente la historia lineal, continuista y convertir su sueño progresista en un caos pesadillesco, es ejemplar una vez más. Lo que Meiling Jin llama "el arte secreto de la Invisibilidad" crea una crisis en la representación de la persona $y$, en el momento crítico, inicia la posibilidad de la subversión política "(Bhabha, op. cit.: 77).

Esa es la subversión del Ratón que encarna, metafóricamente, la capacidad mutante y sabia del sujeto amenazado por el Otro, múltiple y poderoso, frente al que responde con una inteligencia estética que configura los trazos políticos de un nuevo y diferente héroe cultural.

Examinando la historia desde el punto de vista del estilo, de los tropos del narrador que la cuenta, Francisco Arroyo, el relato se construye sobre la base de la paradoja y la antítesis. El héroe es pequeño, cuando se convierte en "ratón ", pero su hazaña, que consiste en finalizar con sus enemigos, es "grande". El ratón no tiene embarcación, no obstante, a sus contendores, que llegan desde el mar, navegantes osados y con ánimo beligerante, los derriba. Sólo deja uno, el testigo, cuyo relato, sirve para dar sentido a sus hechos y también para contarlos frente a los sálam, de modo de poder dar un giro a las contiendas bélicas y poder vivir en paz.

La construcción del relato, dice Agambem (2000), permite el conocimiento de la historia y la comprensión de sus sentidos. Así hoy día podemos comprender el cuento del Ratón como una gran metáfora de las luchas de vida de los kawésqar en el sur de Chile. Y podemos ver la ironía y el humor risueño del narrador cuando desestabiliza los polos binarios occidentales de comprensión de la realidad: entre lo superior y lo inferior; lo pequeño, lo grande. El ratón no es ni lo uno ni lo otro, negocia entre ambos espacios culturales, proponiendo un tercer espacio de enunciación: un "entre", desde el cual se genera, zigzagueante, el sujeto épico y heroico del relato, el que va más allá de las antítesis que conjugan la historia desde el modelo dominante y que, para asombro y estupor de sus enemigos, se instala en un nuevo relato que disemina la historia de su exilio y abandono y que finalmente, llegando al tercer motivo del relato, que es su conversión en un sujeto libre y, por lo tanto, un héroe, alguien que alcanza a ser invencible, pues no conoce la derrota.

Es, además, un héroe diestro, no sólo un guerrero, sino también un hábil cazador y recolector, que sabe como guardar el alimento para los días de escasez y mal tiempo, y cómo conseguirlo, lo que lo convierte en un hacedor de cultura, alguien en quien se formaliza el ideal de un kawésqar.

La rapidez prodigiosa ante los ojos de los otros no es más que el despliegue de su otredad, característica que la mirada del poder le otorga, como diferencia entre su ser y el sentido. Esta rapidez era tanta que podía dejar cocinando erizos y correr al cerro, y volver sin que la comida se hubiese quemado:

Kuosó jeáftæes kerhá ak'uás aselai eik'olájer-s kuo kekiájeks-k'enák aselái eik'olájer-s kuo. Kius léjes ku k'iújef-terrék awás ka kuteké k'ec'á-kámna sa hau... c'appac'éwel čečél-kerk kuterré akér kekéčalk asá ak'uá qálkserk asá-k'ejeháker eik'olájer-s kuo.

Y después se dice, se cuenta, que echaba erizos a la fogata e inmediatamente salía corriendo [al cerro] a mirar. Salía a mirar [al mirador] mientras que en el campamento dejaba cocinando [su comida] y sin que ésta se hubiese quemado... retornaba corriendo [cuando los erizos] que había 
echado a la fogata aún estaban intactos, al llegar los comía, los quebraba y los comía, se cuenta.

(Aguilera-Tonko, 2010-2011: 10, §§ 52-53)

El primer sentido aparencial es sin duda lo fantástico para los ojos de los Saelam y por extensión de quien ocupa el lugar del Yo poderoso, ante quien el Ratón despliega su insondable otredad, pero el juego estratificado de estos signos presentes en el ratón, se refieren al inextricable laberinto de su ser que le permite camuflarse de pequeño y/o grande según su necesidad; de visible o de invisible; siempre de modo veloz, según el deseo de quien sabe disimular lo arcaico - su procedencia detestada por sus enemigos- y traducirlo en una mutación de fuerzas que le permiten , primero, salvar su vida; segundo; vengar a su familia, tercero, reorganizar los paradigmas simbólicos de los szélam y poner su imaginario, su cuerpo, su hermano (de padre sæélam) y su madre en el centro de la ley.

Pero dentro del grupo Szélam, hay un sabio (el testigo) que actúa de fuerza apaciguante con los otro intentando frenar la encarnizada riña de su grupo. Actúa como susurro, significante de una fuerza que demuestra la lenta horadación del sistema simbólico del grupo:

"Sæélam tóu séjep æesterré akér aqás-ker-s kok æes-kiáu wæe če čečáu-ko-áče-sekué," æesk'ak. "Ka ak'uás ka ku táu jetźl čečáu-jetákser-kar ku táu-s k’a jetás-kar sekué," æesk'ák.

"Cuando los otros Szelam bajen navegando a remo por allá por el sur, yo me voy a quedar [aquí] en esta tierra," así [expresaba el Szélam sabio]. "Por qué habéis de andar [en el territorio del ratón], acaso para sellar vuestra suerte, acaso para que os ataque otra vez?" así [dijo].

(Aguilera-Tonko, 2010-2011: 16, §§ 90-91)

El clímax de la narración es la emergencia de la Madre, la que detona el cambio; fuerza móvil entre dos direcciones enunciativas: la del Hijo perdido y la de los Sálam. Y dice: "quiero ir a verificar a ese lugar":

Kuósos sa kiafáro kius c’ap ka kuteké asós aselái eik'olájer-s kiot kuos aqalái jelái-hójok eik'osekčéjerhójok. "Kawésqar ka kuteké qak čo akuér-ahák asó čo asá-kečé-hójok kuteké čečáu æs-kiáu akér asá-kečé aqáče-hójok-kerrá-akstá-ar? askét..." æesk'ák. "Ka kuteké jehána kuteké kéwo-kanána alc’ó-kanána- akstá-akstá-hójok-qe-kuor," æesk’ák. "Ku kiáu ka kuteké léjes os táu-s če jenák kuo. Kiuk ka kuteké jenák kuteké jenák jetának-hor-ket hannó sekiárkep ka kuteké jeksór-haáp," æesk'ák.

Después, de un momento a otro la que había sido su madre, se dice, se cuenta, ella lo fue a buscar y navegó a remo, se cuenta. "Cuando me embarqué abandoné a un pequeño que yo mecía, lo abandoné cuando me vine para acá. ¿qué habrá sido de él?" así [dijo la madre]. "Habrá muerto, habrá muerto de hambre, de sed," así [expresó la madre]. "Quiero ir a verificar a ese lugar. Allí estará [mi hijo], estará viviendo, he aquí que para mí me es conocido y ahí lo reconoceré," así [dijo la madre].

(Aguilera-Tonko, 2010-2011: 18, §§ 100-104)

Es interesante destacar el juego del simulacro que elabora el Ratón, que consiste en preparar un escenario en que pretende no estar solo: pone en su carpa cabezas de tonina como si fueran personas. Todo ello para engañar a los Sálam, pretendiendo que estos compañeros del ratón se encuentran dormidos. Incluso el mismo ratón los arenga e insta a que se levanten:

... tonina kaftálqar so sa kuósos kius lówo kawesqá kuteké ak'uás ka kuteké coipo kuteké laálte káwes táwonk kerrákso-k'ejehák eik'olái-s kuo. Kuo háute akér kuos atókčes k'ak ja ačáal atál kuos, talái atókče čečáu-kerrákso alákso-s k’ak atæél ačáal atál kuos, kuosá Szélam aksárro-kar sa kuos.

... las que había sido las cabezas de toninas y que se asemejaban a la de los lobos las tapaba con pieles de coipo y de nutria, se cuenta. [En el interior de la carpa] al otro lado [de la fogata] estaban [las cabezas de las toninas] asemejándose a muchas personas, estaban como acostadas y como si se hubiesen tapado a sí mismas, tapadas permanecían, y era para engañar a los Szelam.

(Aguilera-Tonko, 2010-2011: 19, §§ 110-113)

Los Sálam entran, ven los cuerpos cubiertos con pieles de coipo y nutria, y los ensartan con sus flechas. Desde el otro extremo de la carpa, el Ratón los mira, irónico, hiriente y los observa diciendo, "iPuede que venga una embarcación!”:

Hannó kuos kuo háute kuterré akér jenák ka kuteké kius c’apaks-kar jetaqána ktep jenák kuteké hernák čæef̌enák eik'olájer-s kuo. Kuos jejehák 
eik'olájer-s kuos ku háute akér kius... kius kučelákso ak'uás aselái eik'olájer-s kiuk kerrákso atál ačáal atál kuo fkiar kte hápar kuos. Kuosá sæfténak ka kuteké æesk'ák ak'uás aselái eik'olájer-s kuos: "K'ewá-pas wa zestqal áltqa-k'ejehák ka kuteké jejehák-akstáhap-he!" æesk'ák. "Ka kuteke asé-s kajéča kuteké akstá-ker," æesk'ák.

He aquí que [él] estaba al otro lado [de la fogata] trabajando con el arpón trabajando con la flecha, la estaba cepillando y lijando se cuenta. Y lo estaban mirando [los Sźlam] y al frente sus... decían, contaban que estaban sus compañeros acostados y tapados, a los cuales [los Sźlam] habían ensartado [con sus flechas]. Y [el ratón] dio una orden [a sus compañeros] de esta manera, se dice, se cuenta: "¡Oigan! ¡Levántense y miren [el entorno]", así [dijo]. "Puede que venga una embarcación," así [dijo].

(Aguilera-Tonko, 2010-2011: 20, §§ 115-119)

Actúa así porque ya ha logrado traspasar la franja que lo señalara como derrotado; porque ha logrado transformar su mundo y el de sus enemigos gracias a sus estrategias de lucha política.

Y es entonces cuando la Madre emerge y trata de poner paz en la situación. Es el hermano del ratón el que comienza a correr sobre los sargasos, como un signo de identificación con el ratón:

Atqásap kiáno jenák kius taksóktek ak'uás aselájer kuosá kuos atakiáræes lálahoi ak’uás aselái eik'olájer-s kuos. Ku jáu hápar lálahoi ka kuteké ječésok kte hápar kekiáhoi eik'olájer-s kuo. Kius taksóktek ak'uá aselájer kuos ku k’iót jenák kuo jeksór atakiáræes kekiáhoi kuos.

He aquí que el hermano del ratón que allí vivía, se dice, se lanzó al agua y llegó nadando la tierra], dicen, se cuenta. Llegó nadando a tierra y llegó corriendo por encima de los sargazos, se cuenta. Se decía que era su hermano el que estaba [viviendo] en la parte trasera [de la isla] y al verlo se tiró al agua y llegó corriendo a tierra.

(Aguilera-Tonko, 2010-2011: 24, §§ 146-148)

Este sin embargo, no logra calmar al Ratón, sino la Madre acompañada de su marido Szélam, quien, sabiendo desde su inconsciente, que otra vez lo dejarán vivir, le reclama desde una forma triádica:

"Tariépska kúkta aqáhoi ka kuteké aksekuál jáutep sas asó ktep čémnak ka séwel aqé he?” æesk'ák
“Acaso [el ratón] no ha de matar al que llega navegando a remo en son de paz, al que atraca [en la playa] y a los que desembarcan a tierra?" así [dijo].

(Aguilera-Tonko, 2010-2011: 28, §172)

Con ironía se expresó el Szélam, pero esa ironía y el conocimiento de esa voz intermedia, que traduce el lenguaje sálam al del ratón, logra apaciguarlo. Paralelamente la madre intenta detener la furia de ambos bandos y logra calmar las iras; se hace reconocer por el Hijo y la calma se restablece. Prueba de ello es el banquete, ofrenda de paz y de unión.

La madre y su hijo (el hermano del ratón ) se quedan en el lugar. De toda esta épica, resulta que permanecen como huella las cabezas de lobo y las de las toninas, como largas piedras que sobresalen en el canal:

Kius jetéso ka kuteké lówo kaftálqar kuteké sákstar kaftálqar hójok eik'olájer kiuk árka kúkstai. K’iesáu kuokuór halí čams kstái akér árkap tæl-atálhójok tæel-akstá-kečéjer-atál.

Se cuenta que sus vestigios, las que eran las cabezas de lobos, las cabezas de toninas, se encuentra en el canal que está hacia arriba del campamento. Son piedras largas y delgadas que sobresalen erguidas del agua y que allí estarán.

(Aguilera-Tonko, 2010-2011: 31, §§193-194)

Y todos los lugares por donde el Ratón miraba el horizonte son los cerros frente al campamento. Tanto el cerro que se llama Kséja-t'áskar y el cerro que se llama K'ejá-ákstar son los cerros por donde subía corriendo el héroe; lo mismo que el cerro Kseltzélkar, que es tabú, existe la prohibición de mirarlo. Las huellas del ratón se diseminan como si fuesen sagradas; los nombres de esa naturaleza habitada por el héroe, devienen sagrados, por la fuerza nominante de la historia que deviene en sí misma ejemplar y paradigmática.

Tenemos entonces otro héroe que, solo, se recupera de los daños causados a su familia y adquiere todas las habilidades de un adulto por sus propios medios y aún más: se destaca por sus dotes, invierte su suerte en la caza y pesca, por lo tanto, tiene una alta producción de víveres.

El ratón consigue con la venida de su madre y su acción reparadora, rescribir la Historia y poder 
integrarse al grupo desde un lugar superior, como Héroe.

Esta historia nos muestra un héroe más de tierra, que en la vida doméstica desarrolla sus virtudes que son de gran fomento para la vida cultural. Desde luego, el Ratón, una vez que se produce la reconciliación, gracias a la figura bienhechora de la Madre, logra emerger como un personaje positivo que se impone por sus méritos en el grupo.

\section{CONCLUSIÓN}

En conclusión, los héroes kawésqar en el "cuento de Annápas" se miden el uno en el otro; sólo que en este texto de diferentes niveles de lectura, sólo un hombre debe mostrar su poder: el territorio es pequeño; no hay espacio a la pluralidad.

Aterrájes es el héroe más desdichado; se queda solo, sin su familia, en una isla y sin su embarcación; privado de afectos y de sus utensilios como marino. El texto lo convierte en " piedra o árbol".

Annápas tampoco logra la estabilidad: su beligerancia en ocasiones y su poder logran causar la ira de los jotes que lo dejan sin su hija, ya que ella muere y podemos inferir su muerte a consecuencia del malhadado pacto, que ha dejado al héroe con la responsabilidad de mantener libre de intrusos el coto de caza y a la vez, de asumir la representación del poder de su grupo.

La exagerada beligerancia de Annápas le trae consigo envidias y odios; riñas y contiendas habidas en otro tiempo desatan sus efectos en la acción de los jotes, que recae sobre el lugar femenino de su familia.

Sea ganador o perdedor, los dos héroes se miden cara a cara con el infortunio, pero Annápas sobrevive y Aterrájes muere. El uno es la cara turbada del otro. Pero juntos se miden, porque los poderes deben manifestarse, exhibirse, como señala Foucault (1978), el poder debe ser exhibido y representado. Para ser respetado, Annápas debe ser temido y su voz debe ser escuchada. Aterrájes debe salir del lugar; su visita se frustra; se cae, no logra sino una desventura. De retorno, solo en su isla, las penas le llueven, es el retrato de un "ethos" sin calma, sumido en la melancolía y la frustración.

El ratón en cambio se muestra como un héroe más positivo: pero, gracias a la palabra de la madre que opera de intermediaria, su figura se redime a nivel social y simbólicamente su figura. Pese a ser pequeñito, es un gran hombre, pareciera advertir y moralizar el texto, dentro de sus retóricas literarias: la antítesis y la exageración que, operando con el tópico de la superabundancia y gracias a una mezcla de humor y magia dan a este relato su valor político y estético.

Es decir, para los kawéskar, la familia como núcleo es un centro de afecto y desarrollo cultural, que, a pesar de los vaivenes de la vida nómade, le da a hombres y mujeres, un sentido de entrañamiento y pertenencia.

El Cuento de Annápas es misterioso, sobretodo en el episodio de Aterrájes. Es notorio que entre ambos hay un vínculo, pero no una alianza, por lo que Aterrájes es desalojado de la isla, lo que le trae la grave depresión que le significa la muerte. Pero el cuento moraliza, no deja esta muerte en vano; el que la ocasiona está también interdicto: le raptan a su hija y a su sobrina. Y la hija se petrifica como le sucediera a Aterrájes.

El texto kawésqar escoge la figura metonímica como aquella en la que se materializa una posibilidad vedada en un sitio; por ejemplo; la relación de doble quiasmo entre Aterrájes y Annápas con la hermana de uno y el hermano del otro. Ellos no se contactan; lo hacen cruzadamente sus hermanos.

Es decir, uno de los hermanos puede, vía matrimonio acercarse a la isla y obtener amparo y nutrición; el otro, no debe acercarse. Una elipsis fundamental ronda la metonimia y posibilita el quiasmo: lo que es imposible a uno de los héroes, lo es para el otro: Para uno de los hermanos, late la vida; para el otro, la muerte.

Lo mismo ocurre con las dos niñas raptadas por los jotes. Una vive, la otra, no. Sus cuerpos están ahí también como espejos alternos, que refractan, metonímicamente la historia de Aterrájes y Annápas, pero desde el ataque por indefensión, en que no hay posibilidad de respuesta.

El cuento de Annápas es más dramático y angustioso, en la medida en que no hay cómo escapar de la fatalidad, que como un significante letal, rodea el texto bajo la figura de los dobles, las siniestras duplas, en que tan sólo una perdura: la de los hermanos, en tanto existe entre ellos la diferencia de género.

El texto narrado en varios episodios, resalta por la magnitud de sus niveles de sentido, por el 
espesor de sus connotaciones léxicas y semánticas, por la parquedad de su dialogismo, por la acendrada dureza de sus párrafos. Es una tragedia, semejante a la de Caín y Abel en La Biblia, y El Libro de Job, en el caso de Aterrájes.

Pero la defensa del territorio tacha (encubre, vela) el gran secreto del texto, su motor, el incesto, que configura a Aterrájes como el perdedor, el navegante solo, que expresa, un terror del marino kawésqar, la soledad, que trae, la petrificación, como se sabe, una forma de castración.

La narración del Ratón es más humana y cercana al alma kawésqar por tratarse de la puesta en escena de las tácticas y estrategias de un solo ser contra muchos; además, un ser que sabe reponerse de la desdicha y lo hace de manera soberbia, como un gran guerrero y un gran cazador, pescador y mariscador. Sin contar sus habilidades para la artesanía y el cuidado en la preservación de los alimentos.

El cuento representa el ladinismo, la astucia desarrollada por un héroe que sabe disminuirse o engrandecerse para desaparecer o reemerger ante su enemigo, derrotándolo. Representa también la victoria por sobre el abuso; la reparación de una ley del sentido y la reconstitución de la familia, con el nuevo hermano, que porta milagrosamente una seña de identidad con él.

Pero esta nueva familia es un grupo de paz. Se la ha ganado y es por ello, que la narración retorna al lugar de origen. Desde donde comienza el trauma, se teje la reparación; así ya no hay embarcaciones que desarmen, con violencia, la familia; sólo hay una bien conquistada tierra de fortuna en la que las alianzas de hermanos se recomponen bajo el prisma del reconocimiento y el afecto.

Lo que nos dejan estos cuentos kawésqar en su oralidad ritual es la memoria de cómo hacer frente al dolor y a la frustración, desde el texto del Ratón, y cómo se ha de ser cauto en la agresividad, por un lado, en el texto de Annápas, puesto que la violencia y la muerte, son fuerzas que desencadenan efectos inusitados, cuya verdad yace, inescrutable, en el lugar menos protegido, como las niñas del grupo.

El castigo a Aterrájes parece ser exacerbado: una mezcla de azar y otra de necesidad de poner un límite a sus actos que contravenían las "normas" de Annápas. Pero ese castigo, que lo elimina de la isla así como de toda la Tierra, deja como efecto, el sentimiento de que si bien el caos forma parte de los planes humanos, una mayor solidaridad con Aterrájes, tal vez hubiera desembocado en otro desenlace de mayor solidaridad y afecto. $Y$ tal vez la tragedia de los jotes asesinos no hubiera ocurrido, puesto que estos sí vienen a trasgredir toda norma, matando al grupo de Annápas y a su familia. La existencia de otro héroe, castigado por una leve infracción, hubiera ayudado a detener el Mal, encarnado en los jotes.

Esa parece ser la parte "pedagógica" de estos relatos, explicación por cierto tentativa y que carece de pretensión de verdad absoluta, ya que finalmente, desde los dos cuentos, los kawésqar saben, mejor que esta lectora, que el caos, el mal, la anarquía constituyen una parte no menor de la existencia humana. Y quizá estos cuentos exorcizan las fuerzas del mal y bien, de eros y thanatos, de la familia amante y el hostil agresor, recomponiendo el Mapa de estos grupos étnicos con héroes que deben trascender su propia humanidad y su dolor, para ir hacia el imaginario colectivo y reafirmar su mundo simbólico con la esperanza y el deseo de una Ley que se una a la justicia.

Por ello, pienso, la necesidad de expresar esas verdades estéticas como formas de comprender el universo, poniendo en figuras estéticas la dimensión fantasiosa con la que el hombre y la mujer kawésqar imaginan su destino. Los poemas de Annápas y del ratón hablan del asombro del universo y de la inescrutable necesidad de tejer y destejer leyes de prohibición y desacato, así como de la importancia del héroe, del líder que impone un modelo cultural para que la comunidad oriente de modo pacífico su vida sobre los mares procelosos del sur de Chile.

\section{BIBLIOGRAFÍA}

AGAMBEM, G. 2000. Lo que queda de Auschwitz. (El archivo y el testigo). Editorial Pretextos, Valencia.

AGUILERA F., O. 2011. Relaciones con el mundo real en los relatos de mitos kawésqar. MS.

AGUILERA F., O. y J. TONKO. 2009. Cuentos Kawésqar. Fundación de Comunicaciones, Capacitación y Cultura del Agro, FUCOA. Ministerio de Agricultura; Programa Orígenes, Corporación Nacional de Desarrollo Indígena, CONADI. Santiago.

2010-2011. Cuento del Ratón. (T-PE-240407=1a \& 1b). Documento de trabajo. Proyecto FONDECYT No. 1100334. MS. 
2011. Cuento de Annápas. (T-PE-27027=1). Documento de trabajo. Proyecto FONDECYT No. 1100334. MS.

BARTHES, R. 1970. La Aventura Semiológica. Paidós, Barcelona. 1975. Lo obvio a lo obtuso. Paidós, Barcelona.

BENVENISTE, E. 1977. Problemas de lingüística general. Editorial Siglo XXI, México.

BHABHA, H. 1994. El lugar de la cultura. Manantial, Buenos Aires.

DERRIDA, J. 1975. La Escritura y la Diferencia. Anthropos, Madrid.

FOUCAULT, M. 1978. Vigilar y castigar. Editorial Siglo XXI, México.

GENETTE, G. 1971. Figuras I y Figuras II. Lumen, Barcelona.
GREIMAS, J. A. 1971. Semántica Estructural. Gredos, Madrid. JAKOBSON, R. 1970. Ensayos de lingüística general. Ariel, Barcelona.

LACAN, J. 1975. Écrits. Seuil, Paris. 1987. La Familia. Argonauta, Buenos Aires.

LÉVI- STRAUSS, C. 1986a. Lo crudo y lo cocido. Fondo de Cultura Económica, México.

1986b. La miel y las cenizas. Fondo de Cultura Económica, México.

2006. Antropología Estructural. Fondo de Cultura Económica, México.

SPIVAK, G. 1985. In Other Worlds. Routledge, New York. ICO, G. 1995. Ciencia Nueva. Tecnos, Madrid. 
